\title{
Composition and properties of soils developed within the ash disposal areas originated from peat combustion (Tyumen, Russia)
}

\author{
Alexandr Konstantinov ${ }^{1, *}$, Andrey Novoselov ${ }^{2}$, Elizaveta Konstantinova ${ }^{3}$, Sergey Loiko ${ }^{4,5}$, \\ Alina Kurasova ${ }^{4}$, Tatiana Minkina ${ }^{3}$ \\ 1 University of Tyumen, Institute of Environmental and Agricultural Biology (X-BIO), 6 Volodarskogo St., 625003, Tyumen, Russia \\ 2 University of Tyumen, Institute of Earth Sciences, 2 Osipenko st., 625002, Tyumen, Russia \\ 3 Southern Federal University, Academy of Biology and Biotechnology in the name of D. I. Ivanovsky, 194/1 Stachki ave., 344090, \\ Rostov-on-Don, Russia \\ 4 National Research Tomsk State University, BIO-GEO-CLIM Laboratory, 36 Lenina st., 634050, Tomsk, Russia \\ 5 Tomsk Oil and Gas Research and Design Institute (TomskNIPIneft), 72 Mira st., 634027, Tomsk, Russia \\ * A. Konstantinov, konstantinov.alexandr72@gmail.com
}

Received: June 18, 2019

Accepted: January 24, 2020

Associated editor: $Ł$. Uzarowicz

\section{ORCID iD}

Alexandr Konstantinov http://orcid.org/0000-0002-6950-2207

Andrey Novoselov http://orcid.org/0000-0001-8589-2316

Elizaveta Konstantinova http://orcid.org/0000-0002-9836-8721

Sergey Loiko htt://orcid.org/0000-0003-2020-4716

Tatiana Minkina $\quad$ http://orcid.org/0000-0003-3022-0883

\section{Keywords}

Spolic Technosols

Peat

Fly ash

Carbonates

\begin{abstract}
Electrical power generation by burning fossil fuels leads to the formation of a significant amount of industrial waste that is often stored at ash disposal sites, which leads to a negative impact on the environment. Therefore, studies devoted to soil formation within such areas are rather sufficient for planning their reclamation. The proposed paper presents the results of a study of soil development at the inactive self-grown ash disposal area of Tyumen combined heat and power (CHP-1) plant (Western Siberia, Russia), formed due to the combustion of peat from the local Tarman deposit. Four soil pits representing different areas of ash dumps with grassy and woody vegetation were selected for detailed studies. The laboratory analyses included chemical, mineralogical and microscopic studies. The obtained results showed that the studied soils are characterised by a poorly developed humus horizon and strong stratification of the ash parent material and can be classified as Spolic Technosols. The studied technogenic soils are characterised by neutral and alkaline $\mathrm{pH}$ values, high LOI values, diversity of pedogenic carbonates and strong heterogeneity of the profile, due to the alteration of layers composed of fly and bottom ash material. These peculiarities of soils are related to properties of peat ashes, technology of peat consumption, and the intensity of weathering under cold continental climate conditions. The main indicators of pedogenic processes are the formation of humus horizons, the decrease in alkalinity in the upper part of the profile, disturbance of the primary stratification of the parent material, and the formation of pedogenic carbonates. It is possible to suppose further evolution of studied soils towards Andosol-like soils.
\end{abstract}

\section{Introduction}

Solid fuel power plants remain an important energy source in many regions of the world. Electrical power generation by burning fossil fuels leads to the formation of a significant amount of industrial wastes, e.g. fly and bottom ash (Ahmaruzzaman, 2010; Yao et al., 2015; Li et al., 2018). Despite the intensive development of technologies for ash treatment and recycling, the storage of solid-fuel waste of thermal power plants in special engineering structures remains the most widespread practice (Blissett and Rowson, 2012).

The generation of electrical energy by burning fossil fuels (primarily coal), is one of the main features of the power industry for the territories of the Russian Federation located to the east of 
the Urals. On the one hand, this is due to the presence of large coal basins (Chelyabinsk, Kuznets, Kansk-Achinsk, Irkutsk, etc.) that provide the local raw materials for the fuel and energy enterprises of these regions (Kurlenya and Cheskidov, 2001). On the other hand, it is also due to the low density of population and the specific features of the electrical power infrastructure of Siberia and the Russian Far East (Makarov et al., 2010).

At present, there are both active and inactive ash disposal areas in most cities of the Urals, Siberia, and the Russian Far East (Delitzin et al., 2012). These facilities are often located in the immediate vicinity of residential areas and have a negative impact on the environment and human health due to ash emissions, water pollution, withdrawal and degradation of land (Haynes, 2009; Zen'kov et al., 2015; Krechetov et al., 2019). Accordingly, studies devoted to the formation of vegetation and soil cover within these areas are important in the context of assessing potential environmental risks associated with the long-term operation of such objects, as well as for planning measures for their reclamation (Makhnev and Makhneva, 2010).

A significant scope of the research on this issue is devoted to reclamation and revegetation of ash disposal areas, as well as the methods of restoration of biological activity (Rakov and Chibrik, 2009; Pandey, 2015). At the same time, less attention is paid to the soil development on technogenic deposits of thermal power plant waste dumps. Detailed investigations of soil evolution within the ash disposal sites have only been carried out for parts of Central and Eastern Europe. The results of studies devoted to soil formation at ash dumps in Poland, Germany, and Serbia showed that pedogenesis on such substrates is largely determined by the nature of the used fuel (bituminous coal or lignite ashes) (Zikeli et al., 2002, 2004, 2005; Uzarowicz and Zagórski, 2015; Weber et al., 2015; Uzarowicz et al., 2017, 2018a, 2018b; Kostić et al., 2018). The differences in the mineral and chemical composition of the ashes due to the diversity of the original fuel, as well as the technological features of specific enterprises, lead to a variety of possible pathways of soil evolution.

Peat along with coal and lignite was often used as a fuel for power plants in Russia during the Soviet period, especially in 1930-1960 (Tcvetkov, 2017). At present, there is almost no use of these mineral resource at large thermal power plants in Russia, except for some enterprises in the European part of the country. The technological difficulties of using peat as fuel at large power plants result in incomplete and chuffing fuel combustion and the formation of a significant number of underburned particles (Kim et al., 2014). During the period when peat was often used as one of the main fuels, ensuring fuel combustion efficiency was a significant problem, as peat from different parts of the one deposit may differ in composition and humidity.

The paper presents the results of a study of soils developed at the ash dumps of Tyumen combined heat and power (CHP-1) plant. Unlike most ash disposal areas of large electric power plants in the Urals and Western Siberia, ash-and-slag wastes from this enterprise are products of the combustion of peat from local deposits (Suslova et al., 2008). Therefore, the present paper shows the peculiarities of the soil formation and the properties of soils formed in areas of self-overgrown ash disposal sites formed as a result of peat combustion.

\section{Study area}

The ash disposal site of Tyumen CHP-1 plant includes two dumps with a total area of about 100 hectares (Dump 1 - approx. 54.0 ha, Dump 2 - approx. 46.0 ha) (Suslova et al., 2008) located in close proximity to the business and historical centre of Tyumen city (Fig. 1). The deposition of combustion products was terminated more than 30 years ago due to the conversion of the power plant to gas. There were no special measures for the reclamation of the disposal area and at present, gradual self-overgrowth is occurring within its territory (Chygov et al., 2007). The surface of the dumps is usually flat, though there are small depressions with a depth of 1-3 m below ground level (b.g.l.). Dump 1 has a more diverse and complex relief. The groundwater level varies significantly depending on terrain elevation, from $0.5-0.6 \mathrm{~m}$ b.g.l. in depressions and up to $2 \mathrm{~m}$ b.g.l. or more in the elevated areas. The climate of the study area is continental. The average long-term annual air temperature is $0.7^{\circ} \mathrm{C}$; the average annual precipitation is $524 \mathrm{~mm}$.

The vegetation cover has a mosaic distribution pattern and includes two main types of plant communities: tree-shrubbery and grassy (Suslova et al., 2008). The tree-shrubbery community includes the following main trees: balsam poplar (Populus balsamifera L.), aspen (Populus tremula L.), various species of willow (Salix sp.), and ash-leaved maple to a lesser extent (Acer negundo L.). Scots pine (Pinus sylvestris L.) is rare; its distribution areas are confined to the peripheral parts of the ash disposal area. Open spaces covered with grassy vegetation occupy about half of the area of Dump 1 and less than a third of Dump 2 (Fig. 1). The grassy communities are dominated by bush grass (Calamagrostis epigejos (L.) Roth) and common reed grass (Phragmites australis (Cav.) Trin. ex Steud.); species such as great nettle (Urtica dioica L.), fireweed (Chamaenerion angustifolium (L.) Scop.), and coltsfoot (Tussilago farfara L.) play a significant role in plant cover.

The primary soil formation lasts 30-40 years (the time of soil development at Dump 1 was 10 years longer than that at Dump 2). It is hardly possible to study the properties and composition of the primary ashes, due to the long-term conservation of the disposal site.

\section{Materials and methods}

The field studies of the soil cover at the ash disposal areas of Tyumen CHP-1 plant were carried out in the summer period of 2017. Two pairs of soil pits (Fig. 1) representing areas covered with tree and grass vegetation for both ash dumps were chosen for detailed studies (pits 1 and 4, 3 and 2, respectively) (Konstantinov et al., 2018). Samples for analytical studies were taken from each morphologically well-defined horizon or layer. A field description of the soils was made according to the Guidelines for Soil Description (FAO, 2006). Soils were classified according to the World Reference Base of Soil Resources (IUSS Working Group WRB, 2015). The colour pattern of the soil horizons and the technogenic parent material was evaluated according to the Munsell Soil Color Charts. The full-size images of the studied soil pits are available on the Photosoil visual database of soils and ecosystems 
(website 1). Samples for further analytical studies were dried and sieved through $2 \mathrm{~mm}$ sieves.

The analysis of the particle size distribution was performed with a laser diffraction particle size analyser LS 13320 Beckman Coulter (USA) after the preliminary treatment of soil samples with sodium pyrophosphate. Soil textural classes were defined according to the USDA textural classification (Soil Survey Staff, 2014): sand $(2-0.05 \mathrm{~mm})$, silt $(0.05-0.002 \mathrm{~mm})$, and clay $(<0.002 \mathrm{~mm})$. The $\mathrm{pH}$ values $\left(\mathrm{H}_{2} \mathrm{O}\right.$ and $\left.1 \mathrm{M} \mathrm{KCl}\right)$ were measured in suspensions with soil/liquid ratios equal to $1: 2.5$ for mineral or $1: 5$ for organic samples by a potentiometric method. The total organic carbon (TOC) content was determined by the Tyurin titrimetric method of wet oxidation (Vorobyova, 2006). Oxalate extractable forms of iron $\left(\mathrm{Fe}_{\mathrm{o}}\right)$ and aluminium $\left(\mathrm{Al}_{\mathrm{o}}\right)$ were determined according to the Tamm's and the Zonn's methods, dithionite extractable forms of iron $\left(\mathrm{Fe}_{\mathrm{d}}\right.$ ) according to the Mehra-Jackson's method (Vorobyova, 2006). The concentrations of $\mathrm{Fe}_{\mathrm{o}}, \mathrm{Al}_{\mathrm{o}}$, and $\mathrm{Fe}_{\mathrm{d}}$ in the extracts were measured by means of spectrophotometry using a spectrophotometer SmartSpec Plus Bio-Rad (USA). The concentrations of the major oxides were determined by X-ray fluorescence analysis with the use of a spectrometer Spectroscan Max-GV Spectron (Russia). Loss on ignition (LOI) was measured by igniting sample at a temperature of $1000^{\circ} \mathrm{C}$ and measuring the weight loss.

Semi-quantitative determination of the mineral composition was carried out using X-ray diffraction (XRD) analysis on a diffractometer DRON-2 Burevestnik (Russia) in the range of 3-40
${ }^{\circ} 2 \theta$. The XRD patterns were processed using GeoQuant software to delete automatic recognition errors. Micromorphological studies of selected samples were carried out in thin-sections using a polarization microscope Eclipse LV100POL Nikon (Japan), as well as using a scanning electron microscope TM3000 Hitachi (Japan) with a X-ray surface elemental analysis EDS system Quantax 70 Bruker (Germany).

\section{Results}

\subsection{Soil morphology and classification}

The soils developed at the ash dumps of Tyumen CHP-1 plant are characterised by the presence of the poorly developed O horizon (5-7 cm thick), as well as the AC horizon (15-30 cm thick) transitional to the technogenic parent material. The lower boundary of the AC horizon is better defined in the areas covered with woody vegetation. It is marked by the sharp decrease in the number of large horizontal tree roots, as well as by higher preservation of the initial stratification. The colours of $\mathrm{O}$ and $\mathrm{AC}$ horizons vary from dark gray (10YR 4/1) to black-gray (2.5YR 3/1). The forest litter, consisting of aspen and willow leaves of varying degrees of decay, occurs at the sites covered with woody vegetation.

The technogenic parent material represents an alternation of dense layers of coarse-silty, bluish-gray (2.5Y 5/1-6/1), or brownish

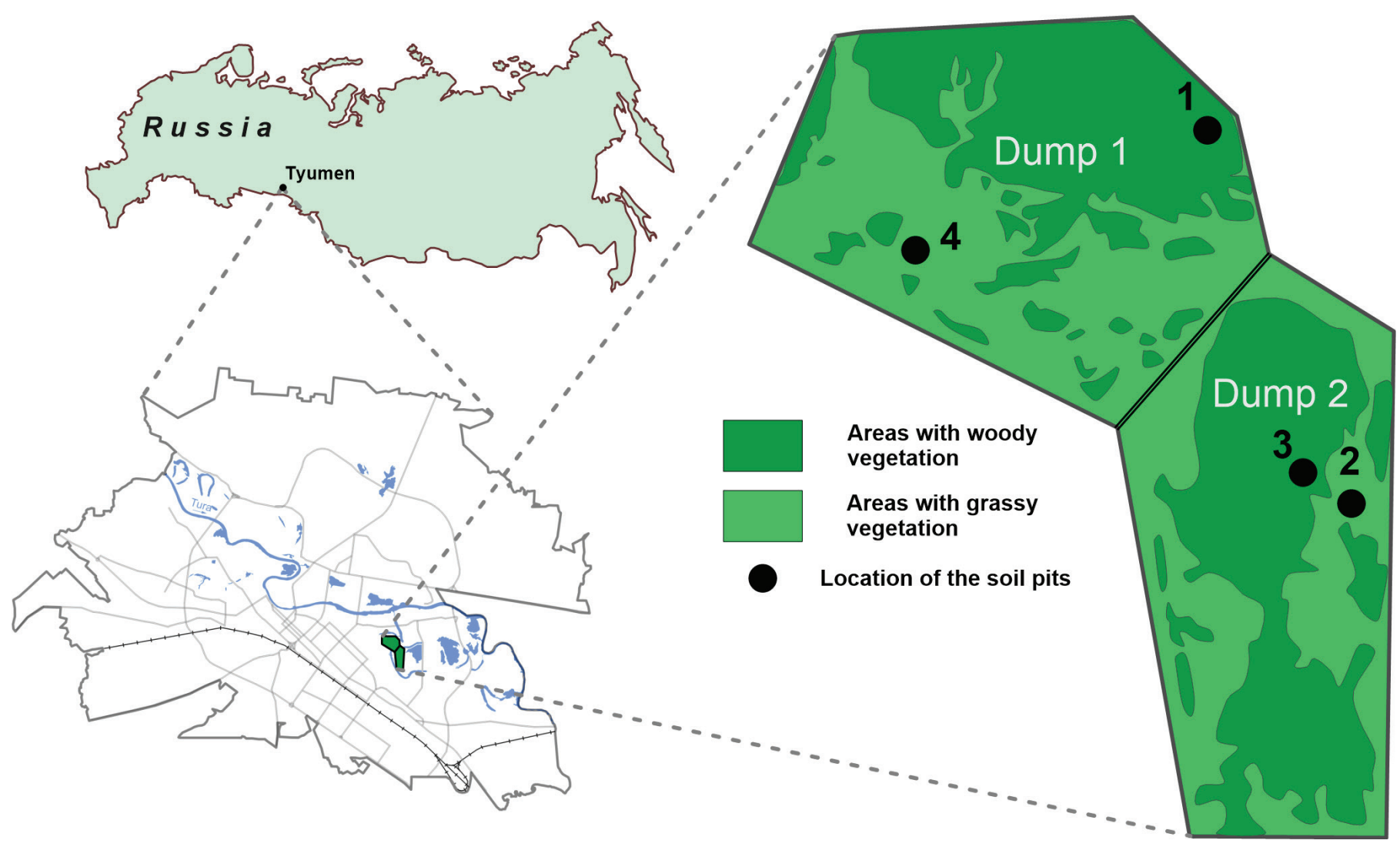

Fig. 1. Location of the study area within the territories of Russia and the city of Tyumen, as well as the location of soil pits within the ash disposal area. 
(10YR 2/2) material, sometimes with a cream shade (10YR 5/2) and loose dark gray (N2.5, 2.5Y 2.5/1-3/1) layers of sandy material that contains large particles ( $\geq 2 \mathrm{~mm}$ ) of the underburned material and construction debris. Layers composed of the silty material often have signs of cementation. Signs of cementation in studied soils were rather rare and were observed as thin $(<1 \mathrm{~cm})$ brownish interlayers in the bottom of the profiles only for soils that develop under grassy vegetation.

Soils developed within Dump 1 show a higher degree of parent material transformation, related to the active development of the root systems of woody plants. The thickness of layer $(\mathrm{O}$ and AC horizons) intensively affected by the soil formation processes is $30-40 \mathrm{~cm}$ in pits 1 and 4 . In soils developed within Dump 2, this value is somewhat fewer $(20-25 \mathrm{~cm})$ which is probably due to the shorter period of soil formation.

The soil developed within the local depression under conditions of seasonal water saturation (pit 3) has a well-defined peaty forest litter as well as signs of gleying at a depth of $80-110 \mathrm{~cm}$. This pit is also characterised by the highest degree of preservation of the initial stratification typical for the ash parent material.

According to the WRB (IUSS Working Group WRB, 2015), all studied soils belong to Spolic Technosols. In addition, Arenic/ Loamic, Endoprotocalcic, Fluvic, Hyperartefactic, Laxic, Amphivitric, Stagnic supplementary qualifiers can be used to describe these soils.

\subsection{Texture and chemical properties}

The contents of individual fractions vary significantly in the studied soils (Table 1): clay - 0.7-9.6\%, silt-16.1-83.0\%, and sand $12.0-83.2 \%$. Such variations are related to the distinct stratification of technogenic substrates into layers of fly ash with a noticeable predominance of silt particles and layers of bottom ash with a predominance of sand fraction.

The $\mathrm{pHH}_{2} \mathrm{O}$ values varied in the range of 6.9-7.8 for the OC/ $\mathrm{AC}$ horizons and 6.7-8.2 for the parent material and the $\mathrm{pH}_{\mathrm{KCl}}$ is in the range of 5.6-7.2 and 6.1-8.0 for OC/AC and C horizons, correspondingly (Table 1). Most of the studied soils show an increase in the $\mathrm{pH}_{\mathrm{H}_{2} \mathrm{O}}$ and $\mathrm{pH}_{\mathrm{KCl}}$ values at a depth range of 50-70 cm, which is likely due to the formation of pedogenic carbonates.

The content of TOC varies widely in studied soils from 0.4 to $13.7 \%$ (Table 1 ). The higher values ( $5 \%$ TOC or more) were recorded in the samples representing bottom ash layers, while this value in the fly ash layers usually does not exceed 1-2\%. A similar pattern is characteristic of the soils developed from coal combustion wastes (Uzarowicz et al., 2018b). In general, it should be noted that a high content of TOC is not evidence of the intensity of soil forming processes, as these values are associated more with a high content of carbonaceous underburned particles than with processes of humification of organic remains (Sokolov et al., 2017). The LOI values in studied soils were significantly high reaching values close to $40 \%$ in some horizons.

The variations in the distribution of oxalate-soluble forms of iron $\left(\mathrm{Fe}_{\mathrm{o}}\right)$ and aluminium $\left(\mathrm{Al}_{\mathrm{o}}\right)$, as well as dithionite-soluble iron $\left(\mathrm{Fe}_{\mathrm{d}}\right)$, are presented in Table 1. The higher values of $\mathrm{Fe}_{\mathrm{o}}$ and $\mathrm{Fe}_{\mathrm{d}}$ were recorded in pits 1 and 4 of Dump 1, whereas the lowest values - in pits 2 and 3 of the Dump 2 - formed under conditions of periodic water saturation. Moreover, sufficiently high values of $\mathrm{Fe}_{\mathrm{o}}$ and $\mathrm{Fe}_{\mathrm{d}}$ are characteristic of all studied soils in the upper part of the soil profile ( $\mathrm{O}$ and $\mathrm{AC}$ ). The $\mathrm{Al}_{\mathrm{o}}+1 / 2 \mathrm{Fe}_{\mathrm{o}}$ value exceeds $0.4 \%$ in more than half of the studied soil samples, confirming their vitric properties (IUSS Working Group WRB, 2015).

\subsection{Chemical composition}

The bulk analysis of the soils showed a distinct predominance of three main components, varying within rather wide limits: $\mathrm{SiO}_{2}$ (from 29.81 to $53.36 \%$ ), $\mathrm{Al}_{2} \mathrm{O}_{3}$ (from 9.89 to $30.39 \%$ ), and $\mathrm{Fe}_{2} \mathrm{O}_{3}$ (from 3.80 to $8.11 \%$ ) (Table 2). Higher $\mathrm{SiO}_{2}$ contents (about $50 \%$ ) were recorded in the layers composed of dispersed fly ash, whereas the proportion of the $\mathrm{SiO}_{2}$ in the bottom ash layers is reduced to $35-40 \%$. The $\mathrm{Al}_{2} \mathrm{O}_{3}$ content is characterised by inverse relation. There are no evident patterns in variations of the $\mathrm{Fe}_{2} \mathrm{O}_{3}$ content. The $\mathrm{CaO}$ content in the technogenic soils of the Tyumen CHP-1 plant varies widely from 3.31 to $9.46 \%$, averaging $4-5 \%$. The intra-profile distribution of the $\mathrm{CaO}$ content is characterised by the presence of peaks, which are likely associated with the accumulation of pedogenic carbonates at depths of 70-100 $\mathrm{cm}$. The remaining oxides are in the subordinate position: $\mathrm{MgO}$ (1.20-4.27\%), $\Sigma \mathrm{Na}_{2} \mathrm{O}+\mathrm{K}_{2} \mathrm{O}(\leq 1.5 \%), \mathrm{TiO}_{2}(\leq 1.5 \%), \mathrm{P}_{2} \mathrm{O}_{5}(\approx 0.5 \%)$, $\mathrm{MnO}(=0.1 \%)$.

\subsection{Mineralogical composition}

The majority of the studied samples of fly ash layers present an alternation of very thin interlayers with noticeable differences in both the particle size and the origin of the material. At the same time both layers composed of silty and sandy material have a similar mineralogical composition. The results of X-ray diffraction analysis demonstrate that the main mineral components of technogenic substrates are quartz $\left(\mathrm{SiO}_{2}\right)$ and mullite $\left(\mathrm{Al}_{6} \mathrm{Si}_{2} \mathrm{O}_{13}\right)$, and, in some samples, calcite $\left(\mathrm{CaCO}_{3}\right)$, as well as amorphous substances (glass) (Fig. 2, Table 3). In addition, sodium and potassium feldspars (mainly albite $\mathrm{Na}\left[\mathrm{AlSi}_{3} \mathrm{O}_{8}\right]$ and microcline $\mathrm{K}\left[\mathrm{AlSi}_{3} \mathrm{O}_{8}\right]$ ) are rather abundant. Chlorite, illite, and smectite group minerals were identified among clay minerals. Their total abundance in most samples was rather low and more detailed diagnostics of clay fraction requires further studies. Iron minerals were not identified with the X-ray diffraction analysis, but their occurrence was established during previous microscopic studies (Fig. 3); these are magnetite $\left(\mathrm{Fe}_{3}\left(\mathrm{Fe}^{2+} \mathrm{Fe}^{3+}\right) \mathrm{O}_{4}\right)$, which is one of the main minerals that constitute Fe-bearing microspheres (Sokol et al., 2002), as well as iron-bearing hydroxides and iron oxides.

Apart from quartz and mullite, some samples contain a significant amount of calcite, the distribution of which along the profile reflects the transformation of the primary substrate during the soil formation process. The highest amounts of calcite were recorded at depths of $80-100 \mathrm{~cm}$ in pits 1 and 4, characterising Dump 1, which refers to the highest $\mathrm{pH}$ values (Table 1). The abundance and diversity of secondary carbonates in these soils were confirmed by studies using both an optical microscope, as 
Table 1.

Physical and chemical properties of studied soils

\begin{tabular}{|c|c|c|c|c|c|c|c|c|c|c|c|c|c|c|}
\hline \multirow{2}{*}{ 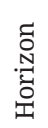 } & \multirow{2}{*}{$\begin{array}{l}\text { Depth } \\
(\mathrm{cm})\end{array}$} & \multicolumn{2}{|c|}{ Munsell Soil Colour } & \multicolumn{3}{|c|}{$\%$ of fractions } & \multirow{2}{*}{$\begin{array}{l}\text { Soil textural } \\
\text { class (USDA) }\end{array}$} & \multirow{2}{*}{ 胥 } & \multirow{2}{*}{ 突 } & \multirow{2}{*}{ 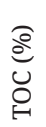 } & \multirow{2}{*}{ 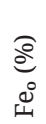 } & \multirow{2}{*}{ 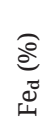 } & \multirow{2}{*}{ 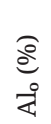 } & \multirow{2}{*}{ 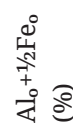 } \\
\hline & & Dry & Moist & Sand & Silt & Clay & & & & & & & & \\
\hline
\end{tabular}

Pit 1. Spolic Technosol (Arenic, Endoprotocalcic, Fluvic, Hyperartefactic, Laxic, Amphivitric)

\begin{tabular}{|c|c|c|c|c|c|c|c|c|c|c|c|c|c|c|}
\hline $\mathrm{OC}$ & $0-5$ & $2.5 Y 3 / 1$ & $2.5 Y 2.5 / 1$ & 78.6 & 20.1 & 1.3 & Loamy sand & 7.4 & 6.8 & 5.1 & 2.31 & 1.98 & 0.11 & 1.26 \\
\hline $\mathrm{AC}$ & $15-20$ & 10YR 5/1 & 10YR 4/1 & 58.4 & 39.9 & 1.7 & Sandy loam & 7.3 & 6.6 & 2.1 & 0.54 & 0.99 & 0.10 & 0.37 \\
\hline $\mathrm{C} 2$ & $40-45$ & 10YR $2 / 2$ & 10YR 2/1 & 29.2 & 67.9 & 2.9 & Silt loam & 8.0 & 7.6 & 0.9 & 0.49 & 1.13 & 0.09 & 0.34 \\
\hline C3 & 70 & $2.5 Y$ 6/1 & $2.5 Y 5 / 1$ & 16.2 & 79.7 & 4.1 & Silt loam & 8.0 & 7.9 & 2.1 & 0.57 & 0.98 & 0.11 & 0.39 \\
\hline $\mathrm{C} 4$ & $95-100$ & 10YR 6/2 & 10YR 4/1 & 22.5 & 71.5 & 6.0 & Silt loam & 8.4 & 8.0 & 1.1 & 1.61 & 2.80 & 0.10 & 0.91 \\
\hline C5 & $110-120$ & $2.5 Y$ 5/1 & $2.5 \mathrm{Y} 4 / 1$ & 65.3 & 32.6 & 2.1 & Sandy loam & 7.7 & 7.7 & 2.6 & 1.14 & 0.88 & 0.09 & 0.66 \\
\hline C6 & 150 & 10YR 5/1 & N3 & 55.9 & 40.6 & 3.5 & Sandy loam & 7.3 & 7.2 & 5.1 & 1.07 & 1.56 & 0.10 & 0.63 \\
\hline
\end{tabular}

Pit 2. Spolic Technosol (Epiarenic, Endoprotocalcic, Fluvic, Hyperartefactic, Laxic, Amphivitric)

\begin{tabular}{|c|c|c|c|c|c|c|c|c|c|c|c|c|}
\hline $0-5$ & 10YR 4/1 & 10YR 3/1 & 79.8 & 19.4 & 0.8 & Loamy sand & 6.9 & 6.0 & 8.8 & 0.98 & 1.70 & 0.11 \\
\hline $5-15$ & 10YR 4/1 & 10YR 3/1 & 67.4 & 30.3 & 2.3 & Sandy loam & 7.7 & 6.4 & 4.7 & 1.15 & 1.53 & 0.18 \\
\hline $20-30$ & 10YR 4/1 & 10YR 3/1 & 73.0 & 25.2 & 1.8 & Loamy sand & 7.8 & 6.4 & 4.5 & 1.22 & 1.55 & 0.12 \\
\hline $35-45$ & N3 & $\mathrm{N} 2.5$ & 23.3 & 67.1 & 9.6 & Silt loam & 7.6 & 6.1 & 5.7 & 0.88 & 1.16 & 0.13 \\
\hline $50-60$ & 2.5YR 5/1 & $2.5 Y R \quad 4 / 1$ & 28.6 & 67.6 & 3.8 & Silt loam & 7.9 & 7.7 & 1.5 & 0.42 & 1.20 & 0.09 \\
\hline $70-80$ & N3 & N2.5 & 57.9 & 37.9 & 4.2 & Sandy loam & 6.7 & 6.2 & 12.7 & 0.91 & 0.97 & 0.11 \\
\hline $100-110$ & 2.5YR 5/1 & $2.5 Y R \quad 4 / 1$ & 48.6 & 49.2 & 2.2 & Sandy loam & 7.9 & 7.8 & 2.0 & 0.57 & 0.88 & 0.09 \\
\hline
\end{tabular}

Pit 3. Spolic Technosol (Endoprotocalcic, Fluvic, Hyperartefactic, Laxic, Stagnic, Amphivitric)

\begin{tabular}{|c|c|c|c|c|c|c|c|c|c|c|c|c|c|c|}
\hline $\mathrm{Oi}$ & $0-2$ & n.d. & n.d. & n.d. & n.d. & n.d. & n.d. & n.d. & n.d. & n.d. & n.d. & n.d. & n.d. & n.d. \\
\hline OC & $2-5$ & 10YR 4/1 & 10YR 3/1 & 76.5 & 21.9 & 1.6 & Loamy sand & 7.1 & 6.1 & 6.1 & 0.68 & 1.44 & 0.11 & 0.45 \\
\hline $\mathrm{AC}$ & 10-15 & $2.5 Y$ 5/1 & $2.5 Y 3 / 1$ & 62.7 & 34.5 & 2.8 & Sandy loam & 7.4 & 5.6 & 5.6 & 0.66 & 0.16 & 0.12 & 0.45 \\
\hline $\mathrm{C} 1$ & 25 & $2.5 Y 5 / 1$ & $2.5 Y 4 / 1$ & 64.9 & 33.9 & 1.2 & Sandy loam & 7.9 & 7.4 & 1.8 & 0.50 & 0.88 & 0.11 & 0.36 \\
\hline $\mathrm{C} 2$ & $35-40$ & $2.5 Y 5 / 1$ & $2.5 Y 4 / 1$ & 69.3 & 29.7 & 1.0 & Sandy loam & 8.0 & 7.3 & 3.5 & 0.90 & 0.74 & 0.16 & 0.61 \\
\hline C3 & 50 & 2.5 YR $4 / 1$ & 2.5 YR $3 / 1$ & 77.3 & 21.4 & 1.3 & Loamy sand & 7.6 & 7.2 & 3.2 & 1.03 & 1.04 & 0.09 & 0.61 \\
\hline $\mathrm{C} 4$ & $60-65$ & $2.5 Y$ 5/1 & $2.5 \mathrm{Y} 4 / 1$ & 65.0 & 33.4 & 1.6 & Sandy loam & 8.0 & 7.6 & 1.7 & 1.09 & 1.09 & 0.10 & 0.65 \\
\hline C5 & 70 & $2.5 Y 5 / 1$ & $2.5 Y 4 / 1$ & 80.9 & 18.3 & 0.8 & Loamy sand & 7.9 & 7.6 & 2.6 & 1.26 & 0.78 & 0.12 & 0.75 \\
\hline C6 & 85 & 2.5YR 6/1 & $2.5 Y R$ 5/1 & 18.5 & 77.4 & 4.1 & Silt loam & 8.1 & 7.9 & 0.8 & 0.92 & 0.32 & 0.09 & 0.55 \\
\hline C7 & 90-95 & 10YR 4/1 & 10YR 3/1 & 77.5 & 21.3 & 1.2 & Loamy sand & 7.9 & 7.7 & 3.6 & 0.82 & 0.87 & 0.09 & 0.50 \\
\hline $\mathrm{C} 8$ & 110 & 2.5YR 6/1 & 2.5 YR $5 / 1$ & 12.0 & 83.0 & 5.0 & Silt & 8.0 & 7.9 & 0.4 & 0.73 & 0.79 & 0.12 & 0.49 \\
\hline C9 & 115 & 2.5YR 6/1 & 2.5YR 5/1 & 40.6 & 57.5 & 1.9 & Silt loam & 8.0 & 7.9 & 8.8 & 1.18 & 0.66 & 0.12 & 0.71 \\
\hline C10 & 140 & $2.5 Y 5 / 1$ & $2.5 Y 5 / 1$ & 76.5 & 21.9 & 1.6 & Loamy sand & 8.0 & 7.9 & 1.6 & 0.55 & 0.65 & 0.15 & 0.42 \\
\hline
\end{tabular}

Pit 4. Spolic Technosol (Amphiprotocalcic, Fluvic, Hyperartefactic, Laxic, Amphivitric)

\begin{tabular}{|c|c|c|c|c|c|c|c|c|c|c|c|c|c|c|}
\hline $\mathrm{Oi}$ & $0-2$ & n.d. & n.d. & n.d. & n.d. & n.d. & n.d. & n.d. & n.d. & n.d. & n.d. & n.d. & n.d. & n.d. \\
\hline $\mathrm{OC}$ & $2-5$ & 2.5YR 3/1 & 2.5YR 3/1 & 73.8 & 24.6 & 1.6 & Loamy sand & 7.5 & 6.9 & 6.9 & 2.19 & 4.32 & 0.13 & 1.23 \\
\hline $\mathrm{AC}$ & $10-15$ & $2.5 Y$ 5/1 & $2.5 Y$ 4/1 & 62.6 & 35.2 & 2.2 & Sandy loam & 7.8 & 7.2 & 3.4 & 2.67 & 2.52 & 0.20 & 1.54 \\
\hline $\mathrm{C} 1$ & $30-35$ & 2.5YR 4/1 & 2.5YR 3/1 & 52.4 & 43.5 & 4.1 & Sandy loam & 8.2 & 7.9 & 1.8 & 1.08 & 0.90 & 0.19 & 0.74 \\
\hline $\mathrm{C} 2$ & $55-68$ & 10YR 5/1 & 10YR 4/1 & 77.9 & 20.9 & 1.2 & Loamy sand & 7.5 & 6.9 & 13.7 & 2.01 & 1.59 & 0.10 & 1.10 \\
\hline C3 & $80-85$ & 10YR 6/2 & 10YR 5/2 & 23.7 & 72.3 & 4.0 & Silt loam & 7.7 & 7.1 & 7.3 & 1.70 & 1.29 & 0.12 & 0.97 \\
\hline $\mathrm{C} 4$ & 100-105 & 2.5YR 3/1 & N2.5 & 83.2 & 16.1 & 0.7 & Loamy sand & 7.5 & 8.0 & 7.1 & 1.14 & 0.56 & 0.13 & 0.70 \\
\hline C5 & 150 & N3 & $\mathrm{N} 2.5$ & 52.4 & 43.5 & 4.1 & Sandy loam & 6.8 & 6.5 & 5.7 & 2.51 & 3.02 & 0.13 & 1.38 \\
\hline
\end{tabular}

n.d. - not determined

well as a scanning electron microscope (Konstantinov et al., 2018). Calcite aggregates and small dispersed intergrowth represent the two main types of pedogenic carbonates. In terms of the composition and inner structure, aggregates are rounded calcite particles occurring as both single grains (pit 2) and agglomerations. The neoformations are confined to textural boundaries or organic residue, in some cases forming layers of carbonate-rich material, which acts as a cement (Fig. 4). Small intergrowths often form massive microstructures with dispersed carbonates. Intergrowth occur as small sheaf-like splices of elongated crystals no larger than $0.3 \mathrm{~mm}$ (Fig. 4). This type of pedogenic carbonates were found only in the soil from pit 4 at a depth of 80-90 cm. 


\section{Discussion}

The specific features and properties of the studied soils are largely determined by the properties of peat as an organic fuel for industrial thermal power plants. One of the distinctive features of the soils formed at the ash disposal areas originating from peat combustion is a higher content of the $<0.002 \mathrm{~mm}$ fraction and a higher content of the silt fraction for layers composed of fly ash and for those with a predominance of bottom ash. It should be noted that the content of the sand fraction in the studied samples does not exceed 90\% even in layers composed of bottom ash. Higher content of clay fraction in studied soils can be explained by the peculiarities of the peats from the Tarman deposit, which were used as the main fuel for Tyumen CHP-1 plant during the 1960s and 1970s. The peatlands at the Tarman deposit occupy a significant territory, varying considerably in ash content (from
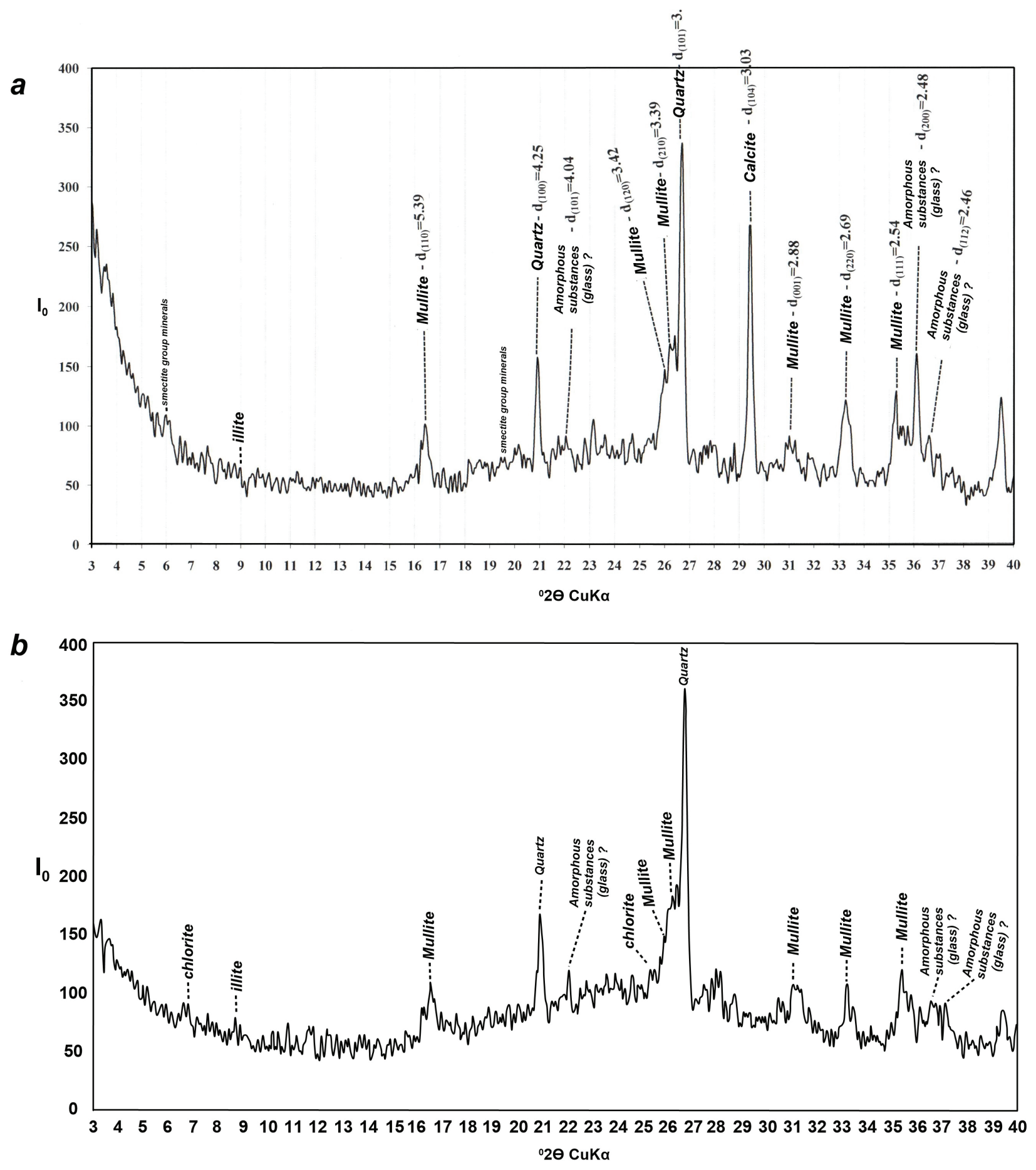

Fig. 2. XRD-patterns of representative samples of soils from ash disposal areas of Tyumen CHP-1 plant, illustrating the peaks related to predominant minerals: a - Pit 4, C3 horizon; b-Pit 2, C5 horizon 

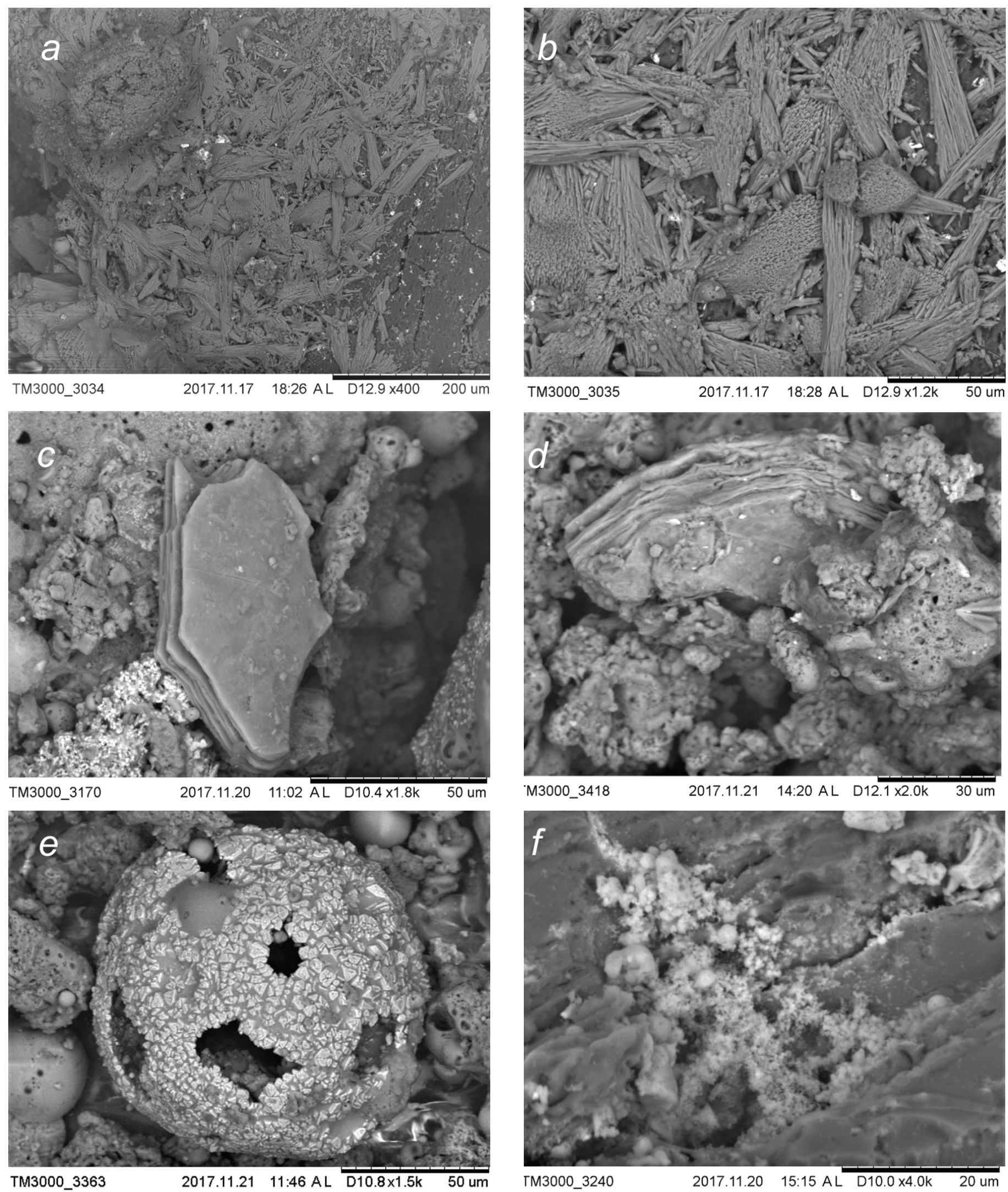

Fig. 3. Selected minerals identified during SEM-EDS studies (the images were made in secondary electron mode): a - splitted calcitic crystals, developing over isometric aggregates (Pit 1, C6 horizon); b - splitted calcitic crystals that form radial clusters (Pit 1, C6 horizon); c - detrital clay ag-

gregate (Pit 4, C4 horizon); $d$ - detrital clay aggregate with low degree of preservation (Pit 2, C6 horizon); e - a hollow microsphere encrusted with octahedral magnetite microcrystals (Pit 3, C5 horizon); f - Fe-oxides microcrystals probably developing over biofilms (Pit 4, C2 horizon) 
Table 2.

Contents of major elements in the fine earth $(<2 \mathrm{~mm})$ of studied soils (in \%)

\begin{tabular}{|c|c|c|c|c|c|c|c|c|c|c|c|c|c|}
\hline Horizon & $\begin{array}{l}\text { Depth } \\
(\mathrm{cm})\end{array}$ & $\mathrm{SiO}_{2}$ & $\mathrm{Al}_{2} \mathrm{O}_{3}$ & $\mathrm{Fe}_{2} \mathrm{O}_{3}$ & $\mathrm{CaO}$ & $\mathrm{MgO}$ & $\mathrm{Na}_{2} \mathrm{O}$ & $\mathrm{K}_{2} \mathrm{O}$ & $\mathrm{TiO}_{2}$ & $\mathrm{P}_{2} \mathrm{O}_{5}$ & $\mathrm{MnO}$ & LOI & Sum \\
\hline \multicolumn{14}{|c|}{ Pit 1. Spolic Technosol (Arenic, Endoprotocalcic, Fluvic, Hyperartefactic, Laxic, Amphivitric) } \\
\hline $\mathrm{OC}$ & $0-5$ & 40.97 & 16.85 & 5.17 & 6.83 & 1.83 & 0.3 & 0.78 & 1.05 & 0.60 & 0.10 & 40.08 & 99.98 \\
\hline $\mathrm{AC}$ & $15-20$ & 45.12 & 29.70 & 4.88 & 3.47 & 1.45 & 0.4 & 0.70 & 1.46 & 0.35 & 0.10 & 30.09 & 99.96 \\
\hline $\mathrm{C} 2$ & $40-45$ & 47.21 & 30.39 & 6.04 & 3.40 & 1.58 & 0.5 & 0.61 & 1.40 & 0.31 & 0.10 & 32.78 & 99.89 \\
\hline $\mathrm{C} 3$ & 70 & 50.50 & 24.58 & 6.25 & 3.31 & 1.53 & 0.4 & 0.62 & 1.44 & 0.31 & 0.10 & 31.23 & 99.82 \\
\hline $\mathrm{C} 4$ & 95-100 & 29.81 & 16.36 & 8.11 & 9.10 & 4.27 & 0.5 & 0.35 & 0.75 & 1.18 & 0.10 & 31.10 & 99.95 \\
\hline $\mathrm{C} 5$ & $110-120$ & 44.71 & 23.02 & 6.73 & 7.93 & 2.16 & 0.6 & 0.51 & 1.32 & 0.42 & 0.10 & 42.24 & 99.95 \\
\hline C6 & 150 & 38.47 & 23.55 & 6.52 & 6.58 & 1.98 & 0.7 & 0.55 & 1.20 & 0.47 & 0.10 & 40.08 & 99.92 \\
\hline \multicolumn{14}{|c|}{ Pit 2. Spolic Technosol (Epiarenic, Endoprotocalcic, Fluvic, Hyperartefactic, Laxic, Amphivitric) } \\
\hline $\mathrm{AC}$ & $0-5$ & 47.86 & 14.11 & 4.89 & 4.47 & 1.43 & 0.4 & 0.72 & 0.92 & 0.50 & 0.10 & 24.56 & 99.96 \\
\hline $\mathrm{C} 1$ & $5-15$ & 52.78 & 23.63 & 4.73 & 3.56 & 1.20 & 0.4 & 0.72 & 1.29 & 0.40 & 0.10 & 10.98 & 99.79 \\
\hline $\mathrm{C} 2$ & $20-30$ & 47.97 & 24.82 & 4.72 & 5.30 & 1.48 & 0.5 & 0.64 & 1.23 & 0.39 & 0.10 & 12.50 & 99.65 \\
\hline $\mathrm{C} 3$ & $35-45$ & 47.02 & 21.54 & 3.80 & 4.89 & 1.32 & 0.5 & 0.51 & 1.17 & 0.37 & 0.10 & 18.60 & 99.82 \\
\hline $\mathrm{C} 4$ & $50-60$ & 53.36 & 21.86 & 5.77 & 3.96 & 1.48 & 0.5 & 0.67 & 1.45 & 0.31 & 0.10 & 10.19 & 99.65 \\
\hline $\mathrm{C} 5$ & $70-80$ & 32.96 & 17.81 & 5.24 & 7.53 & 1.89 & 0.5 & 0.43 & 1.13 & 0.39 & 0.10 & 31.98 & 99.96 \\
\hline C6 & $100-110$ & 51.22 & 21.63 & 6.34 & 4.02 & 1.76 & 0.4 & 0.60 & 1.47 & 0.31 & 0.10 & 12.00 & 99.85 \\
\hline $\mathrm{C} 7$ & 140 & 47.63 & 24.91 & 5.81 & 5.22 & 1.61 & 0.6 & 0.52 & 1.21 & 0.40 & 0.10 & 11.63 & 99.64 \\
\hline
\end{tabular}

Pit 3. Spolic Technosol (Endoprotocalcic, Fluvic Hyperartefactic, Laxic, Stagnic, Amphivitric)

\begin{tabular}{|c|c|c|c|c|c|c|c|c|c|c|c|c|c|}
\hline $\mathrm{Oi}$ & $0-2$ & n.d. & n.d. & n.d. & n.d. & n.d. & n.d. & n.d. & n.d. & n.d. & n.d. & n.d. & n.d. \\
\hline $\mathrm{OC}$ & $2-5$ & 37.68 & 15.47 & 4.51 & 5.55 & 1.56 & 0.6 & 0.72 & 0.98 & 0.63 & 0.10 & 32.08 & 99.88 \\
\hline $\mathrm{AC}$ & 10-15 & 41.37 & 18.89 & 4.12 & 6.41 & 1.55 & 0.7 & 0.47 & 1.10 & 0.39 & 0.10 & 24.66 & 99.76 \\
\hline $\mathrm{C} 1$ & 25 & 44.62 & 25.99 & 5.52 & 6.27 & 1.90 & 0.7 & 0.55 & 1.29 & 0.38 & 0.10 & 11.90 & 99.22 \\
\hline C2 & $35-40$ & 43.08 & 26.21 & 6.37 & 6.01 & 1.90 & 0.7 & 0.52 & 1.41 & 0.38 & 0.10 & 12.74 & 99.42 \\
\hline C3 & 50 & 43.48 & 21.74 & 6.26 & 7.27 & 2.05 & 0.6 & 0.45 & 1.38 & 0.42 & 0.10 & 16.15 & 99.90 \\
\hline $\mathrm{C} 4$ & $60-65$ & 45.56 & 25.52 & 6.23 & 6.77 & 2.11 & 0.5 & 0.49 & 1.44 & 0.41 & 0.10 & 10.50 & 99.63 \\
\hline C5 & 70 & 43.29 & 24.15 & 5.65 & 8.29 & 2.21 & 0.5 & 0.41 & 1.30 & 0.42 & 0.10 & 12.90 & 99.22 \\
\hline C6 & 85 & 50.29 & 20.07 & 6.31 & 4.75 & 1.81 & 0.4 & 0.52 & 1.46 & 0.32 & 0.10 & 13.90 & 99.93 \\
\hline C7 & 90-95 & 43.32 & 24.32 & 6.13 & 7.00 & 2.24 & 0.4 & 0.46 & 1.34 & 0.43 & 0.10 & 14.20 & 99.94 \\
\hline C8 & 110 & 40.26 & 20.27 & 6.17 & 4.74 & 1.96 & 0.4 & 0.59 & 1.33 & 0.34 & 0.10 & 23.43 & 99.59 \\
\hline C9 & 115 & 37.73 & 13.66 & 4.02 & 7.60 & 1.67 & 0.6 & 0.39 & 0.92 & 0.40 & 0.10 & 32.38 & 99.47 \\
\hline C10 & 140 & 35.51 & 19.10 & 5.47 & 4.81 & 1.67 & 0.7 & 0.62 & 1.44 & 0.36 & 0.10 & 30.19 & 99.97 \\
\hline \multicolumn{14}{|c|}{ Pit 4. Spolic Technosol (Amphiprotocalcic, Fluvic, Hyperartefactic, Laxic, Amphivitric) } \\
\hline Oi & $0-2$ & n.d. & n.d. & n.d. & n.d. & n.d. & n.d. & n.d. & n.d. & n.d. & n.d. & n.d. & n.d. \\
\hline $\mathrm{OC}$ & $2-5$ & n.d. & n.d. & n.d. & n.d. & n.d. & n.d. & n.d. & n.d. & n.d. & n.d. & n.d. & n.d. \\
\hline $\mathrm{AC}$ & 10-15 & 40.08 & 21.37 & 7.93 & 6.65 & 2.20 & 0.3 & 0.53 & 1.13 & 0.62 & 0.10 & 18.85 & 99.76 \\
\hline $\mathrm{C} 1$ & 30-35 & 30.09 & 17.01 & 5.22 & 5.20 & 2.02 & 0.5 & 0.46 & 1.10 & 0.51 & 0.10 & 37.65 & 99.86 \\
\hline $\mathrm{C} 2$ & $55-68$ & 32.78 & 12.89 & 6.67 & 8.05 & 2.31 & 0.4 & 0.39 & 1.14 & 0.55 & 0.10 & 34.71 & 99.99 \\
\hline C3 & 80-85 & 31.23 & 18.19 & 8.07 & 8.57 & 2.52 & 0.6 & 0.49 & 1.03 & 0.70 & 0.10 & 28.42 & 99.92 \\
\hline $\mathrm{C} 4$ & 100-105 & 31.10 & 9.89 & 4.69 & 9.46 & 2.14 & 0.7 & 0.29 & 0.74 & 0.36 & 0.10 & 40.30 & 99.77 \\
\hline $\mathrm{C} 5$ & 150 & 42.24 & 24.39 & 6.82 & 4.35 & 1.51 & 0.6 & 0.72 & 1.18 & 0.33 & 0.10 & 17.50 & 99.74 \\
\hline
\end{tabular}

n.d. - not determined

6 to 20\%) throughout the area and often containing a high amount of silty and low content of sandy material (Grekhova, 2005).

Very high LOI values of studied soils are probably related to the technological peculiarities of peat combustion at large power plants. Application of this type of fuel resulted in incomplete and chuffing fuel combustion and therefore resulted in the high amounts of unburned organic fragments in the ashes.
The ash composition is largely determined by the origin of the fuel. The ashes from peat, lignite and combustible shale have a higher content of $\mathrm{CaO}$, while the bituminous coal ashes have predominantly aluminosilicate composition (Yudovich and Ketris, 2005). Therefore, the content of $\mathrm{CaO}$ in the soils under consideration is a little higher than in the Technosols developed from bituminous coal ashes but significantly lower than in soils from 
lignite ashes (Uzarowicz and Zagórski, 2015). At the same time, pH values are much lower in comparison with soils from bituminous coal and lignite ashes studied at the ash disposal sites of Eastern Europe (Uzarowicz et al., 2017, 2018b), which may be interpreted as a result of intensive weathering under conditions of a cold continental climate, as well as peculiarities of ashes originated from combustion of peat from a certain deposit. It is important to mention that we can only speculate about the intensity of peat ash weathering, as the facility has not used this type of fuel for a long time and the initial ashes are not available for analysis.

The main set of soil-forming processes, manifested in all the soils under consideration, is associated with the transformation of organic residues and the disintegration of the technogenic parent material (weathering of the primary silicate, aluminosilicate, and carbon-containing particles). The processes of transformation of the substrate that are observed in the Technosols in the ash disposal areas are similar to the weathering of volcanic ash, but occurring at much higher rates (Warren and Dudas, 1984, 1985; Uzarowicz et al., 2018a). The area under consideration is characterised by conditions of deep seasonal freezing. Along with processes of soil formation and the activity of living organisms, the freeze-thaw cycles in water-saturated layers of dispersed fly ash can also intensify weathering processes.

The formation of secondary carbonates is a characteristic feature of soil formation at ash disposal areas (Uzarowicz et al., $2017,2018 b)$. The amount and the variety of pedogenic carbonates in the studied soils correlate directly with a degree of the soil profile development. A high content of carbonate neoformations and the occurrence of both well-defined large agglomerations and intergrowths in the soils at Dump 1 is due to the longer period of soil formation (the storage of ash and slag wastes was finished 5-10 years earlier) and good drainage, as well as vegetation. The decrease of $\mathrm{pH}$ values in the upper part of the soil profile, the accumulation of organic matter, and the formation of $\mathrm{O}$ and $\mathrm{AC}$ horizons containing soil organic matter in the upper horizons of the pits with a longer period of soil formation, are among other indicators of pedogenesis. The following tendency was not so obvious for $\mathrm{Fe}_{\mathrm{o}}$ and $\mathrm{Fe}_{\mathrm{d}}$, as well these values are very variable along the profile, which is also a typical feature of soils developed from bituminous coal and lignite ashes (Uzarowicz et al., 2017).

Based on the obtained results it is possible to note the important role of the vegetation and local hydrological and geomorphological conditions on the intensity of soil formation processes. The development of the tree vegetation under good drainage conditions leads to the formation of soils with a greater thickness of humus horizons. The large roots of woody plants penetrate deeply into the substrate, break up the initial ash stratification, and contribute to the formation of soil structure, as well as improving the water regime. Based on the composition, properties and the morphology of studied soils it is possible to suggest that further pedogenic evolution would lead to the formation of an Andosol-like soils on the studied disposal sites. The ability of such technogenic substrates to maintain highly productive for herbaceous and woody plant associations suggests that expansive remediation measures are probably not necessary.
Table 3.

Bulk mineralogical composition of the fine earth $(<2 \mathrm{~mm})$ of soils developed on ash deposits based on powder XRD analyses

\begin{tabular}{lcl}
\hline Horizon & Depth $(\mathrm{cm})$ & Minerals \\
\hline Pit 1. & $\begin{array}{l}\text { Spolic } \\
\text { Hyperartefactic, Laxic, Amphivitric) }\end{array}$ \\
OC & $0-5$ & Qz, AS, Mul, Ab, Sm \\
AC & $15-20$ & Qz, Mul, AS, Ab, Mc, Sm \\
C2 & $40-45$ & Qz, Mul, AS, Ca, Ab, Chl \\
C3 & 70 & Qz, Mul, AS, Ab, Sm, Chl \\
C4 & $95-100$ & Qz, Ca, Mul, AS, Ab, Sm \\
C5 & $110-120$ & Qz, Ca, Mul, AS \\
C6 & 150 & Qz, Mul, AS, Ilt
\end{tabular}

Pit 2. Spolic Technosol (Epiarenic, Endoprotocalcic, Fluvic, Hyperartefactic, Laxic, Amphivitric)

$\begin{array}{lll}\text { AC } & 0-5 & \text { Qz, Mul, AS, Ab, Ilt } \\ \text { C1 } & 5-15 & \text { Qz, Mul, AS, Ab, Ilt } \\ \text { C2 } & 20-30 & \text { Qz, Mul, AS, Ca, Ab } \\ \text { C3 } & 35-45 & \text { Qz, Mul, AS, Ab, Mls, Ilt } \\ \text { C4 } & 50-60 & \text { Qz, Mul, AS, Ca, Ab, Sm } \\ \text { C5 } & 70-80 & \text { Qz, Mul, AS, Mc, Ab, Chl, Sm, Ilt } \\ \text { C6 } & 100-110 & \text { Qz, Mul, AS, Ca, Mc, Ab, Sm } \\ \text { C7 } & 140 & \text { Qz, Mul, AS, Ca, Ab, Mc }\end{array}$

Pit 3. Spolic Technosol (Endoprotocalcic, Fluvic Hyperartefactic, Laxic, Stagnic, Amphivitric)

$\begin{array}{lll}\text { Oi } & 0-2 & \text { n.d. } \\ \text { OC } & 2-5 & \text { Qz, AS, Mul, Ab, Chl } \\ \text { AC } & 10-15 & \text { Qz, Mul, AS, Ab, Mc } \\ \text { C1 } & 25 & \text { Qz, Mul, AS, Ca, Sm } \\ \text { C2 } & 35-40 & \text { Qz, Mul, AS, Ca, Ab } \\ \text { C3 } & 50 & \text { Qz, Mul, AS, Ca, Ab, Mc, Chl, Sm } \\ \text { C4 } & 60-65 & \text { Qz, Mul, AS, Ca, Ab } \\ \text { C5 } & 70 & \text { Qz, Mul, AS, Ca, Ab, Sm } \\ \text { C6 } & 85 & \text { Qz, Mul, AS, Ca, Ab, Sm } \\ \text { C7 } & 90-95 & \text { Qz, Mul, AS, Ca, Ab } \\ \text { C8 } & 110 & \text { Qz, Mul, AS, Ca, Ab, Chl } \\ \text { C9 } & 115 & \text { Qz, Mul, AS, Ca, Ab, Chl. Sm } \\ \text { C10 } & 140 & \text { Qz, Mul, AS, Ca }\end{array}$

Pit 4. Spolic Technosol (Amphiprotocalcic, Fluvic, Hyperartefactic, Laxic, Amphivitric)

$\begin{array}{lll}\text { Oi } & 0-2 & \text { n.d. } \\ \text { OC } & 2-5 & \text { Qz, Mul, AS, Ab, Chl, Sm } \\ \text { AC } & 10-15 & \text { Qz, AS, Ca, Ab, Mc } \\ \text { C1 } & 30-35 & \text { Qz, AS, Ca, Ab, Mc, Sm, Ilt } \\ \text { C2 } & 55-68 & \text { Qz, Mul, AS, Ca, Ab, Sm } \\ \text { C3 } & 80-85 & \text { Qz, Mul, AS, Ca, Ab, Mc, Sm, Ilt } \\ \text { C4 } & 100-105 & \text { Qz, Mul, AS, Ca, Ab } \\ \text { C5 } & 150 & \text { Qz, Mul, AS, Ab, Sm }\end{array}$

n.d. - not determined. Minerals are given in a semiquantitative order based on the relation of peak intensities in the XRD patterns. Symbols of mineral phases: $\mathrm{Ab}$ - albite, AS - amorphous substances (glass), $\mathrm{Ca}$ - calcite, Chl - chlorite, Ilt - illite, Mc - microcline, Mul - mullite, Qz - quartz, Sm -smectite group minerals. 


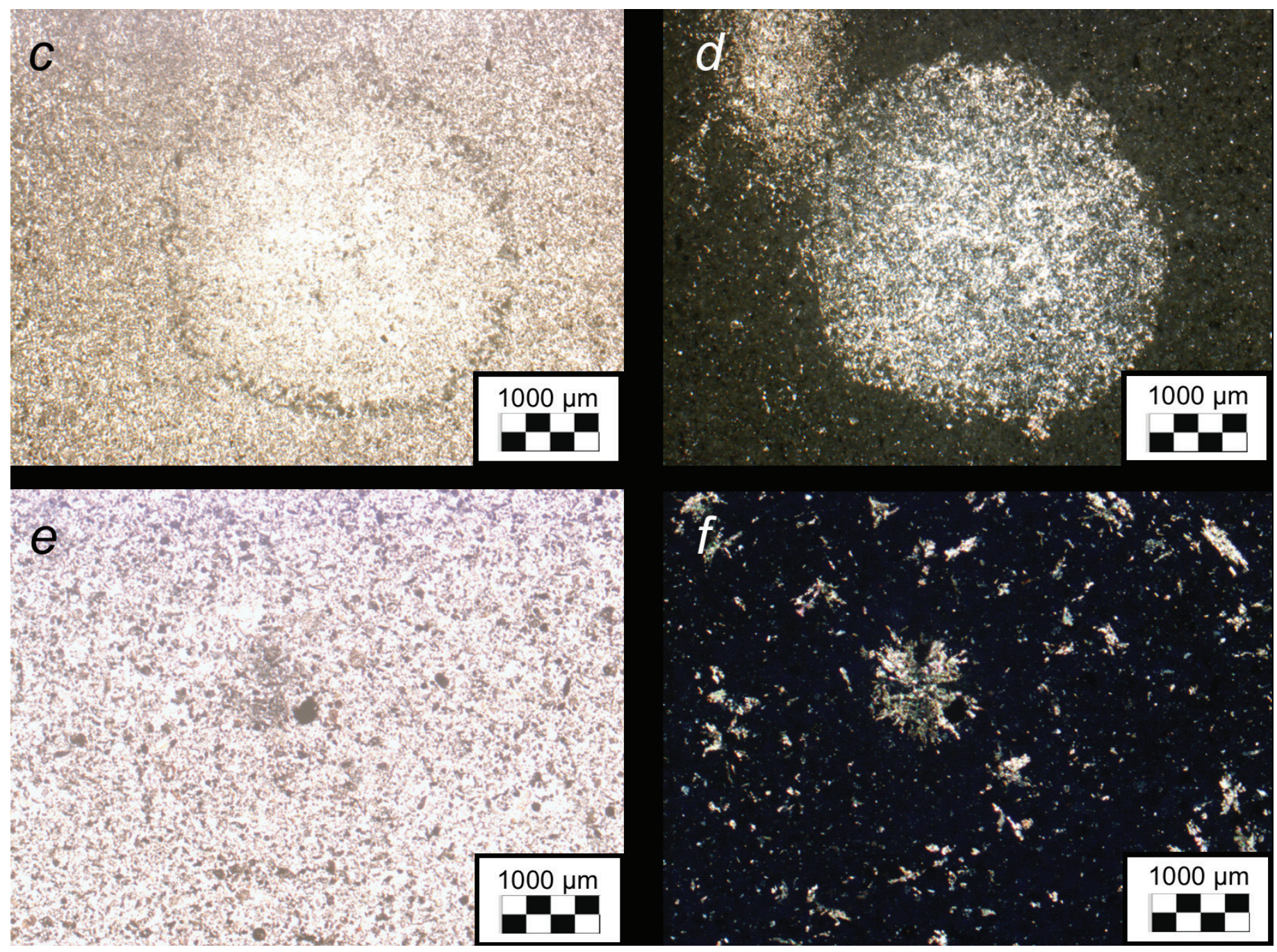

Fig. 4. Diversity of carbonate neoformations: a - carbonate agglomerations attached to micro-texture inhomogeneity zones (Pit 1, C4, PPL); b the same image under cross-polarized light (XPL), zones enriched with

\section{Conclusions}

(1) The soils developing at the ash disposal areas of Tyumen CHP1 are characterised by a poorly developed humus horizon and strong stratification of the ash parent material and can be classified as Spolic Technosols.

(2) The studied soils are characterised by close to neutral $\mathrm{pH}$ values in OC/AC horizons and alkaline in subsoils, high LOI values and strong variability of TOC content along the profile. The $\mathrm{Al}_{\mathrm{o}}+1 / 2 \mathrm{Fe}_{\mathrm{o}}$ value in more than half of the studied soil samples exceeds $0.4 \%$.

(3) Components such as $\mathrm{SiO}_{2}$ (up to $53.36 \%$ ), $\mathrm{Al}_{2} \mathrm{O}_{3}$ (up to $30.39 \%$ ), and $\mathrm{Fe}_{2} \mathrm{O}_{3}$ (up to $8.11 \%$ ) prevail in the chemical composition of the soils of the ash disposal areas of Tyumen CHP-1 plant. The $\mathrm{CaO}$ content is high (3.31-9.46\%, on average 4-5\%). The rest of oxides are in the subordinate position: $\mathrm{MgO}(1.20$ $4.27 \%), \sum \mathrm{Na}_{2} \mathrm{O}+\mathrm{K}_{2} \mathrm{O}(\leq 1.5 \%), \mathrm{TiO}_{2}(\leq 1.5 \%), \mathrm{P}_{2} \mathrm{O}_{5}(\approx 0.5 \%)$, $\mathrm{MnO}(\leq 0.1 \%)$.

(4) The major components of the mineral composition are quartz, mullite, and calcite in individual samples, as well as amorphous compounds (glass). carbonate material are marked with arrows (Pit 1, C4, PPL); c - large roundish carbonate agglomeration developed without visible micro-texture contact (Pit 2, C5, PPL); $\mathrm{d}$ - the same image under cross-polarised light

(5) The main indicators of the soil formation are the formation of horizons of $\mathrm{O}$ and $\mathrm{AC}$, initial signs of pedogenic structure, a decrease of $\mathrm{pH}$ values in the upper part of the profile, the transformation of the primary stratification of technogenic soils by the plant roots, and the formation of pedogenic carbonates.

(6) In the best developed soils of the older section of ash disposal areas under conditions of good drainage, two types of pedogenic carbonates were observed, aggregates and small intergrowths.

(7) Signs of the soil formation are better defined in the soils of elevated areas, covered with woody vegetation, with good drainage and the leaching water regime. The properties and composition of studied soils such as low $\mathrm{pH}$ values in comparison with other soils developed from other ashes, high LOI values and significant amount of clay fraction are determined mainly by peculiarities of peat ashes, as well as by processes of weathering under cold continental climate and deep seasonal freezing. 

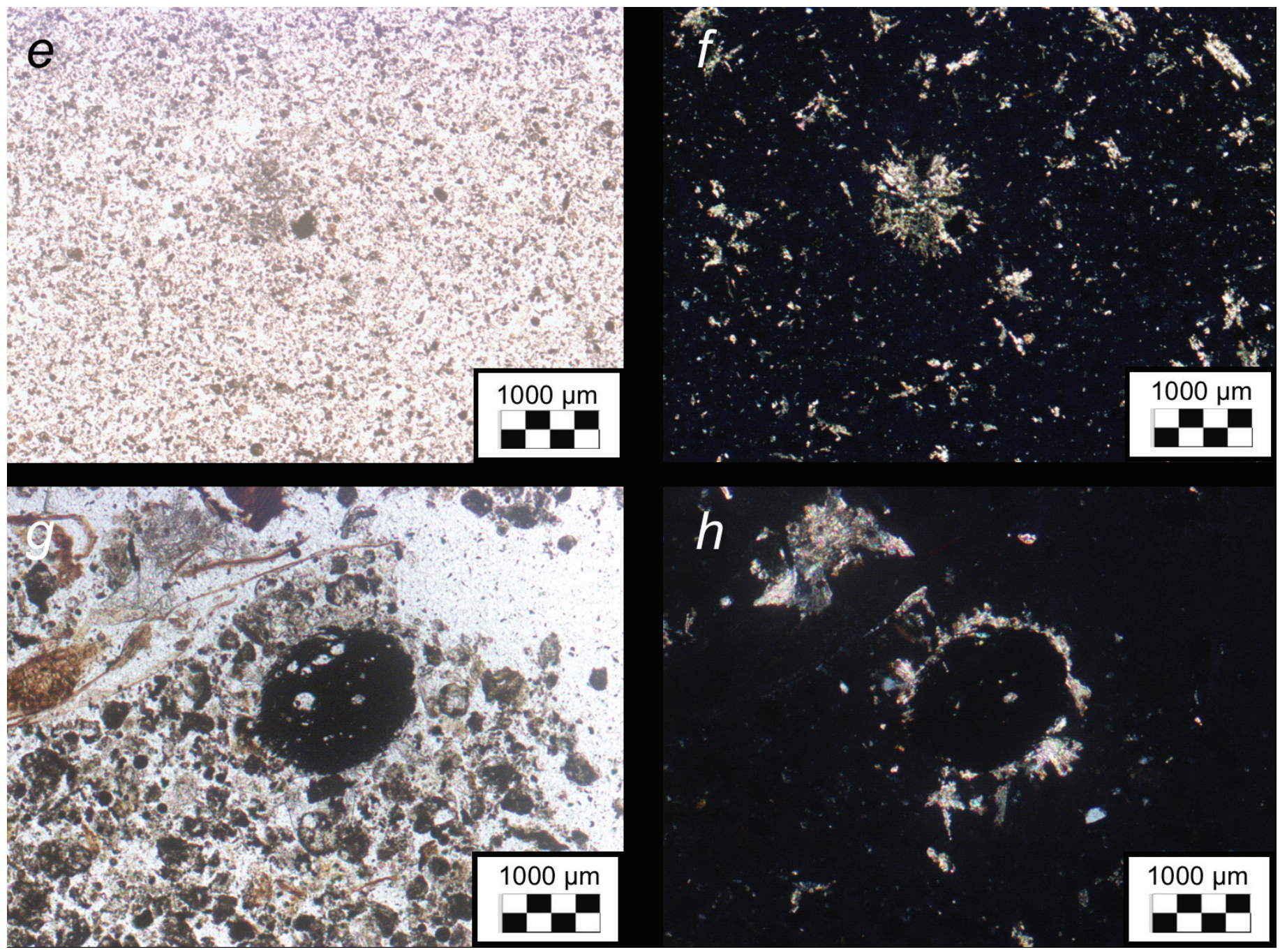

(Pit 2, C5, XPL); e - ash material with massive microstructure and dispersed intergrowths of pedogenic carbonates (Pit 4, C4. PPL); $\mathrm{f}-$ the same image under cross-polarized light (Pit 4, C4. PPL); g - small, radial-blasted

\section{Acknowledgments}

Field studies were funded by RFBR, project number 18-3420129; the analytical studies were supported by the Grant of the President of the Russian Federation, MK-2973.2019.4, and RFBR, project number 19-29-05265. Authors would like to thank the reviewers for constructive comments and suggestions.

\section{References}

Ahmaruzzaman, M., 2010. A review on the utilization of fly ash. Progress in Energy and Combustion Science 36(3), 327-363. https://doi. org/10.1016/j.pecs.2009.11.003

Blissett, R., Rowson, N., 2012. A review of the multicomponent utilization of coal fly ash. Fuel 97, 1-23. https://doi.org/10.1016/j.fuel.2012.03.024

Chygov, B.E., Pariguina, N.G., Suslov, A.V., Atkina, L.I., 2007. The inventory of a ash dump Tumen and methods of a laying out of a park in it. Lesnoy vestnik (Forestry Bulletin) 8(57), 85-90 (in Russian with English abstract). intergrowth of calcite, developing over plant residues (Pit 4, C4. PPL); $h$ the same image under cross-polarized light (Pit 4, C4. PPL)

Delitzin, L.M., Ezhova, N.N., Vlasov, A.S., Sudareva, S.V., 2012. Ash disposal areas of coal's power stations as the threat to environmental safety. Èkologiâ promyšlennogo proizvodstva 4, 15-26 (in Russian with English abstract).

FAO, 2006. Guidelines for soil description. Fourth edition. FAO, Rome.

Grekhova, I.V., 2005. Characteristics on lowland peats of the Transuralian Region and their use я soil fertility recovery. Doctoral (Biol.) Dissertation. Tyumen. (in Russian).

Haynes, R.J., 2009. Reclamation and revegetation of fly ash disposal sites - challenges and research needs. Journal of Environmental Management 90(1), 43-53. https://doi.org/10.1016/j.jenvman.2008.07.003

IUSS Working Group WRB, 2015. World Reference Base of Soil Resources 2014, update 2015 International Soil Classification System for Naming Soils and Creating Legends for Soil Maps. World Soil Resources Reports no. 106. FAO, Rome.

Kim, J.K., Lee, H.D., Kim, H.S., Park, H.Y., Kim, S.C., 2014. Combustion possibility of low rank Russian peat as a blended fuel of pulverized coal fired power plant. Journal of Industrial and Engineering Chemistry 20(4), 1752-1760. https://doi.org/10.1016/j.jiec.2013.08.027

Konstantinov, A.O., Novoselov, A.A., Loiko, S.V., 2018. Special features of soil development within overgrowing fly ash deposit sites of 
the solid fuel power plant. Tomsk State University Journal of Biology 43, 6-24 (in Russian with English abstract). http://dx.doi. org/10.17223/19988591/43/1

Kostić, O., Jarić, S., Gajić, G., Pavlović, D., Pavlović, M., Mitrović, M., Pavlović, P., 2018. Pedological properties and ecological implications of substrates derived 3 and 11 years after the revegetation of lignite fly ash disposal sites in Serbia. CATENA 163, 78-88. https://doi. org/10.1016/j.catena.2017.12.010

Krechetov, P., Kostin, A., Chernitsov, O., Terskaya, E., 2019. Environmental changes due to wet disposal of wastes from coal-fired heat power plant: A case study from the Tula Region, Central Russia. Applied Geochemistry 105, 105-113. https://doi.org/10.1016/j.apgeochem.2019.04.017

Kurlenya, M.V., Cheskidov, V.I., 2001. Prospects of coal mining in Siberia. Journal of Mining Science 37(3), 319-322. https://doi org/10.1023/A:1013162730915

Li, J., Zhuang, X., Querol, X., Font, O., Moreno, N., 2018. A review on the applications of coal combustion products in China. International Geology Review 60(5-6), 671-716. https://doi.org/10.1080/00206814.201 7.1309997

Makarov, A.A., Voropai, N.I., Saenko, V.V., Saneev, B.G., 2010. Regional features of fuel and energy complex. [In:] Yanovsky, A.B. et al. (Eds.), Russia's energy: look into the future". Materials for the energy strategy of Russia 2030. Publishing House "Energiya”, Moscow, 435-460 (in Russian).

Makhnev, A.K., Makhneva, N.E., 2010. Landscape-ecological and population aspects of the strategy of restoration of disturbed lands. Contemporary Problems of Ecology 3(3), 318-322. http://dx.doi.org/10.1134/ S1995425510030100

Pandey, V.C., 2015. Assisted phytoremediation of fly ash dumps through naturally colonized plants. Ecological Engineering 82, 1-5. http://dx. doi.org/10.1016/j.ecoleng.2015.04.002

Rakov E.A, Chibrik T.S., 2009. On the problem of flora formation in in dustrially disturbed land areas. Russian Journal of Ecology 6(40), 448 http://dx.doi.org/10.1134/\$1067413609060125

Soil Survey Staff, 2014. Soil Survey Field and Laboratory Methods Manual. Soil Survey Investigations Report No. 51. Version 2. U.S. Department of Agriculture, Natural Resources Conservation Service.

Sokol, E.V., Kalugin, V.M., Nigmatulina, E.N., Volkova, N.I., Frenkel, A.E., Maksimova, N.V., 2002. Ferrospheres from fly ashes of Chelyabinsk coals: chemical composition, morphology and formation conditions. Fuel 81(7), 867-876. http://dx.doi.org/10.1016/S0016-2361(02)00005-4

Sokolov, D.A., Kulizhskii, S.P., Lim, A.G., Gurkova, E.A., Nechaeva, T.V., Merzlyakov, O.E., 2017. Comparative evaluation of methods for determination of pedogenic organic carbon in coal-bearing soils. Tomsk State University Journal of Biology (39), 29-43 (in Russian with English abstract). https://doi.org/10.17223/19988591/39/2

Suslova, N.G., Atkina, L.I., Chizhov, B.Ye, Agafonov, Ye.Yu., 2008. Construction of recreational objects on the territory of ash-heaps in the town of Tyumen. News of the Orenburg State Agrarian University 2(18), 219-222 (in Russian with English abstract).

Tcvetkov, P.S., 2017. The history, present status and future prospects of the Russian fuel peat industry. Mires and Peat 19(14), 1-12. http://doi. org/10.19189/MaP.2016.OMB.256
Uzarowicz, Ł., Kwasowski, W., Śpiewak, O., Świtoniak, M., 2018a. Indicators of pedogenesis of Technosol developed in an ash settling pond at the Bełchatów thermal power station (central Poland). Soil Science Annual 69(1), 49-59. https://doi.org/10.2478/ssa-2018-0006

Uzarowicz, Ł., Skiba, M., Leue, M., Zagórski, Z., Gąsiński, A., Trzciński, J., 2018b. Technogenic soils (Technosols) developed from fly ash and bottom ash from thermal power stations combusting bituminous coal and lignite. Part II. Mineral transformations and soil evolution. CATENA 162, 255-269. https://doi.org/10.1016/j.catena.2017.11.005

Uzarowicz, Ł., Zagórski, Z., 2015. Mineralogy and chemical composition of technogenic soils (Technosols) developed from fly ash and bottom ash from selected thermal power stations in Poland. Soil Science Annual 66(2), 82-91. https://doi.org/10.1515/ssa-2015-0023

Uzarowicz, Ł., Zagórski, Z., Mendak, E., Bartmiński, P., Szara, E., Kondras, M., Oktaba, L., Turek, A., Rogoziński, R., 2017. Technogenic soils (Technosols) developed from fly ash and bottom ash from thermal power stations combusting bituminous coal and lignite. Part I. Properties, classification, and indicators of early pedogenesis. CATENA 157, 75-89. https://doi.org/10.1016/j.catena.2017.05.010

Vorobyova, L.A., 2006. Theory and practice chemical analysis of soils. GEOS, Moscow. (in Russian with English abstract).

Warren, C.J., Dudas, M.J., 1984. Weathering processes in relation to leachate properties of alkaline fly ash. Journal of Environmental Quality 13(4), 530-538. http://dx.doi.org/10.2134/jeq1984.00472425001300040005x

Warren, C.J., Dudas, M.J., 1985. Formation of secondary minerals in artificially weathered fly ash. Journal of Environmental Quality 14(3), 405-410. http://dx.doi.org/10.2134/jeq1985.00472425001400030019x

Weber, J., Strączyńska, S., Kocowicz, A., Gilewska, M., Bogacz, A., Gwiżdż, M., Debicka, M., 2015. Properties of soil materials derived from fly ash 11years after revegetation of post-mining excavation. CATENA 133, 250-254. https://doi.org/10.1016/j.catena.2015.05.016.

Yao, Z., Ji, X., Sarker, P., Tang, J., Ge, L., Xia, M., Xi, Y., 2015. A comprehensive review on the applications of coal fly ash. Earth-Science Reviews 141, 105-121. https://doi.org/10.1016/j.earscirev.2014.11.016

Yudovich, Ya.E., Ketris, M.P. 2005. Toxic trace elements in Coal. UrB RAS, Ekaterinburg. (in Russian with English abstract).

Zen'kov, I.V., Nefedov, B.N., Baradulin, I.M., Kiryushina, E.V., Vokin, V.N., 2015. Environmental problems during the maintenance of ash-andslag storages in the fuel-energy complex of Russia. Ekologia i promyshlennost Rossii (Ecology and Industry of Russia) 19(2), 24-28 (in Russian with English abstract). https://doi.org/10.18412/1816-03952015-2-24-28

Zikeli, S., Jahn, R., Kastler, M., 2002. Initial soil development in lignite ash landfills and settling ponds in Saxony-Anhalt, Germany. Journal of Plant Nutrition and Soil Science 165(4), 530-536. https://doi. org/10.1002/1522-2624(200208)165:4<530::AID-JPLN530>3.0.CO;2-J

Zikeli, S., Kastler, M., Jahn, R., 2004. Cation exchange properties of soils derived from lignite ashes. Journal of Plant Nutrition and Soil Science 167(4), 439-448. https://doi.org/10.1002/jpln.200421361

Zikeli, S., Kastler, M., Jahn, R., 2005. Classification of anthrosols with vitric/andic properties derived from lignite ash. Geoderma 124(3-4), 253-265. https://doi.org/10.1016/j.geoderma.2004.05.004

website 1: http://www.photosoil.tsu.ru/en 